\title{
RISK ASSESSMENT FOR HAZARDOUS SUBSTANCES STORAGE
}

\author{
Osvaldo Chavarría Acuña \\ National Environmental Technical Secretariat \\ San José, Costa Rica
}

\begin{abstract}
The goal of this article is to demonstrate the general principles of environmental risk assessment for hazardous substance storage. Matrixes, HAZOP, FTA, and Monte Carlo are examples of methodologies that can be used in conjunction with one another. Environmental assessment, which anticipates the physical, biological, and social repercussions of a project, is used in conjunction with risk assessment. A computer system can be utilized to determine the spill's impact region. When evaluating the probability of an event, and hence the risk, it is vital to have correct statistical data in order to generate more precise conclusions. Following international guidelines is the greatest method to reduce danger.
\end{abstract}

Keywords-Environmental risk assessment, hazardous substances, environmental impact assessment (EIA)

\section{INTRODUCTION}

Hazardous substance storage is necessitated by the requirement to provide a service such as raw material or fuel. Storage is a risk because if the proper precautions are not taken, accidents might occur, inflicting environmental and health damage. An environmental assessment and a risk assessment are used to determine the viability of this activity. An environmental evaluation precisely analyzes the risk, which might be environmental and health-related, posed by the operation of this activity.

\section{GENERAL OVERVIEW OF HAZARDOUS SUBSTANCES}

A hazardous chemical is one that, by its very nature, causes or can cause short-term or long-term harm to human health, flora, fauna, commodities, and/or the environment. (Silva, n.d.)

Chemical hazards and toxic substances pose a wide range of health hazards (such as irritation, sensitization, and carcinogenicity) and physical hazards (such as flammability, corrosion, and explosibility). (OSHA, 2020)

These chemicals are commonly utilized as raw materials in industry for various transformation processes. They are also employed on a smaller scale in homes (paintings, solvents, and varnishes).
Another application is as an energy source, where everyone is heavily reliant on fossil fuels. The world depends on a great deal of its energy in the form of fossil fuels. (Sciencing, 2020)

The objective of crude distillation is to fractionate crude oil into light-end hydrocarbons (C1-C4), naphta/gasoline, kerosene, diesel, and atmospheric resid. Some of these broad cuts can be marketed directly, while others require further processing in refinery downstream units to make them saleable. (Parkash, 2003).

Storage of hazardous chemicals can lead to technical disasters, such as accidents involving chemical products, radioactive products, or biological agents (toxic or infectious materials). They can create explosions and flames, as well as other severe impacts. When the exposed populace is aware of chronic or slow explosions, public health concerns become urgent, and sanitary authorities' assistance becomes critical.(Ministerio de Salud, 2004)

To give an example, a spill of low-toxicity paraffin material occurred in Limón City, Costa Rica, in 2003, without being detected by authorities or the surrounding residents. It was researched, analyzed, and later submitted to the government on a voluntary basis by the tank's owner.

The vegetation and wildlife showed no hazardous impacts, and the majority of the material was collected from the natural container lagoon. These kinds of incidents, as well as those that aren't reported to authorities or emergency services, demand special attention. (Ministerio de Salud, 2004)

In the year 2003, in Communay, France, at a service station along the motorway, the operators detect a leak after comparing the volume stored to that distributed. The amount leaked is estimated at 6500 litres of diesel, yet no visible trace of this leak is found on the ground or in the station's outfalls. The leak seems to be due to a broken weld on an elbow in the feed manifold at the base of the gas pump meter. The station shuts down all operation, including the pumps that transfer fuel from the storage tanks to the pumping facilities. The manifolds are also immobilized. An emergency order from the prefect, upon recommendation by the inspectors of classified facilities, requires the station operator to demarcate the polluted area, to estimate the extent of soil and ground water pollution using 


\section{International Journal of Engineering Applied Sciences and Technology, 2021 \\ Vol. 6, Issue 1, ISSN No. 2455-2143, Pages 77-87 \\ Published Online May 2021 in IJEAST (http://www.ijeast.com)}

piezometers, and to determine the exact causes of the accident, within 7 days. The absence of any danger is to be demonstrated before the facilities may resume operation. The ground is permeable in this location and the risks of pollution are high. ( Ministère de l'Ecologie, de l'energie, du développement durable et de l'amenagement du territoire, 2009)

In 2018, a fire broke out at the Bharat Petroleum factory in Mahul, Mumbai, injuring numerous people.. Fire and blast in Hydrocarbon plant containing 72 ton hydrocarbon unit caused damage to nearby plants. (Singh \& Lewis, 2018)

In the year 2015, in the Brazilian city of Rio de Janeiro, A heating unit at a Petrobras depot in Brazil used to treat fuel for ocean-going ships exploded on Wednesday, killing two workers. ("Petrobras fuel tank explodes", 2020)

Many more examples of accidents that have occurred around the world and over time can be provided. For the proper storage of hazardous compounds, safety guidelines have been devised. If their physical-chemical qualities are not properly regulated, they can cause harm to the environment and human health.

To install a tank on a field, environmental and social feasibility must be determined through an environmental impact assessment, which is a scientific-technical administrative procedure that allows you to identify and predict what effects may impact the environment, an activity, or a project, quantify and calculate them, and use that information to make decisions. (Decree 31849, 2004)

In general, an Environmental Impact Assessment (EIA) is an analytical technique that examines the environmental characteristics of a project or activity in relation to its location.

Because some sites might help flora and fauna in ecosystems, localization is an important factor to consider.

Wetlands, which are ecological associations where species can share multiple environments that allow them to grow in fool plains, without or low oxygen levels, or soaked with salts, are one of the most fragile ecosystems. These species have developed to take use of the environment's resources, such as plentiful water, abundant nutrients, and high production. (Áreas y parques, 2020)

Riverbanks, also known as riverbank woodland, riparian zone, and ciliate forest, are significant biologically. The term "riverside vegetation" refers to the significance of preserving rivers and lakes, similar to how eyelash and ciliate eye protect human eyes. (Guía ecológico, 2020)

In a maximum flood, riparian forest also plays a significant role. When an ecosystem is in good shape, it will have a greater impact on water in the event of heavy rainfall. As a result, if vegetation is in good condition, it can cushion the effect and intensity of water, reducing potential harm. (Durán, 2020)
Hazardous compounds can reach surface water bodies such as rivers and springs, causing deaths in dependant species the water sources indicated, depending on storage capacity and surroundings such as waterproofing and field topography.

A spill can reach subsurface water even if it does not reach a surface water body. Groundwater and surface water are interconnected and can be fully understood and intelligently managed only when that fact is acknowledged. If there is a water supply well near a source of contamination, that well runs the risk of becoming contaminated. If there is a nearby river or stream, that water body may also become polluted by the ground water. (EPA, n.d.)

Figure 1 shows a plume of contaminants rising from an underground leaky tank, which is transported away by gravity. The chemical takes a specific course as it travels due to the direction of ground water, contaminating water supplies.

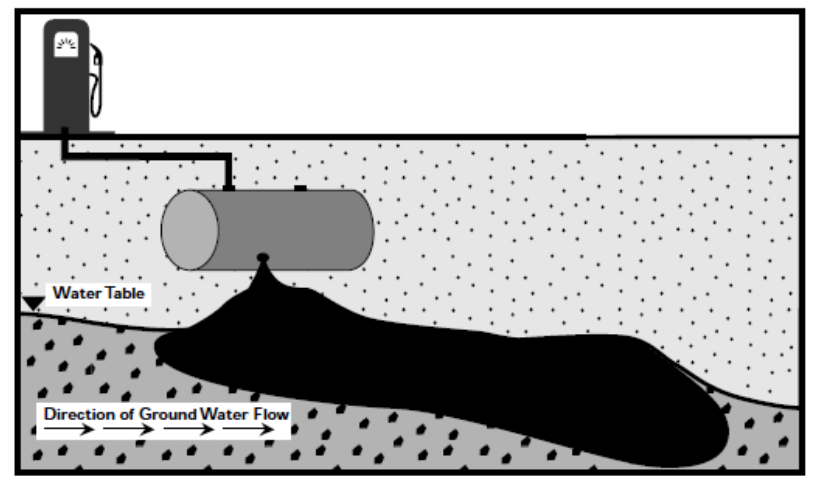

Fig. 1. Contaminants erupt from an underground fuel tank. (EPA, 2020)

Spillages can also have societal consequences if they reach a public water supply well, as they might create health problems among inhabitants practically instantly. If they reach rivers, in addition to the health issues described, they may have an influence on water usage such as fishing and recreation.

In general, in order to address all of an activity's affects, it is important to employ a well-established and scientifically approved technique that confronts all project impact activities in terms of potentially impacted environmental aspects. (Decree 32966, 2006)

\section{EIA METHODOLOGIES BY INTERACTIVE MATRIXES}

In EIA, interactive matrixes are frequently utilized. The project or activity activities are displayed on the vertical axis, and the environmental element is displayed on the horizontal axis, in a single interactive matrix. (Canter, 1997)

One of the most common matrixes is the Leopold Matrix. The Leopold matrix (LM) was developed in 1971, in response to the Environmental Policy Act of 1969. The LM provides a system 
for the analysis and numerical weighting of probable impacts. (Ponce, 2020)

This matrix has: (1) on the horizontal axis, the actions which cause environmental impact, and (2) on the vertical axis, the existing environmental conditions which may be affected by those actions. This provides a format for comprehensive review of the interactions between proposed [anthropogenic] actions and environmental factors (characteristics and conditions). (Ponce, 2020)

The 88 factors stated are a mixture of situations and traits that can be noticed in the vertical. There are 8000 interactions in all.

Table 1. Actions listed in the horizontal ais of the Leopold matrix (Ponce, 2020)

\begin{tabular}{|c|c|c|}
\hline \multirow{17}{*}{$\begin{array}{r}\text { ACTIONS } \\
\text { (Proposed } \\
\text { actions which } \\
\text { mae cause } \\
\text { environmental } \\
\text { impact) }\end{array}$} & \multirow{13}{*}{$\begin{array}{l}\text { Modification } \\
\text { of regime }\end{array}$} & Exotic flora or fauna introduction \\
\hline & & Biological controls \\
\hline & & Modification of habitat \\
\hline & & Alteration of ground cover \\
\hline & & Alteration of groundwater hydrology \\
\hline & & Alteration of drainage \\
\hline & & River control and flow modification \\
\hline & & Canalization \\
\hline & & Irrigation \\
\hline & & Weather modification \\
\hline & & Burning \\
\hline & & Surface or paving \\
\hline & & Noise and vibration \\
\hline & \multirow{4}{*}{$\begin{array}{c}\text { Land } \\
\text { transformation } \\
\text { and } \\
\text { construction }\end{array}$} & Urbanization \\
\hline & & Industrial sites and buildings \\
\hline & & Airports \\
\hline & & Highways and bridges \\
\hline
\end{tabular}

\begin{tabular}{|c|c|}
\hline & Roads and trails \\
\hline & Railroads \\
\hline & Cables and lifts \\
\hline & $\begin{array}{l}\text { Transmission lines, pipelines and } \\
\text { corridors }\end{array}$ \\
\hline & Barriers including fencing \\
\hline & Channel dredging and straightening \\
\hline & Channel revetments \\
\hline & Canals \\
\hline & Dams and impoundments \\
\hline & $\begin{array}{l}\text { Piers, seawalls, marinas, and sea } \\
\text { terminals }\end{array}$ \\
\hline & Offshore structures \\
\hline & Recreational structures \\
\hline & Blasting and drilling \\
\hline & Cut and fill \\
\hline & Tunnels and underground structures \\
\hline \multirow{7}{*}{$\begin{array}{l}\text { Resource } \\
\text { extraction }\end{array}$} & Blasting and drilling \\
\hline & Surface excavation \\
\hline & Subsurface excavation and retorting \\
\hline & Well drilling and fluid removal \\
\hline & Dredging \\
\hline & Clear cutting and other lumbering \\
\hline & Commercial fishing and hunting \\
\hline
\end{tabular}


International Journal of Engineering Applied Sciences and Technology, 2021

Vol. 6, Issue 1, ISSN No. 2455-2143, Pages 77-87

Published Online May 2021 in IJEAST (http://www.ijeast.com)

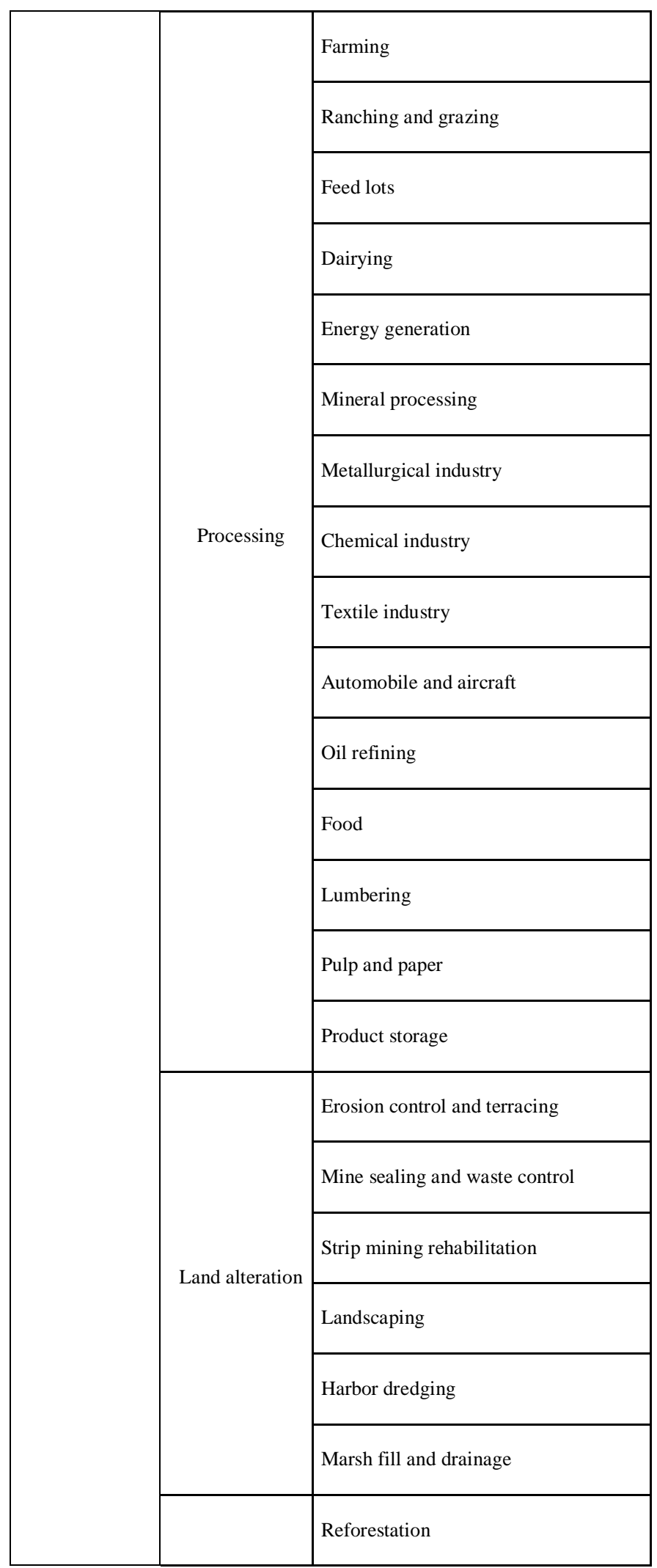

\begin{tabular}{|c|c|}
\hline \multirow[t]{4}{*}{$\begin{array}{l}\text { Resource } \\
\text { renewal }\end{array}$} & Wildlife stocking and management \\
\hline & Groundwater recharge \\
\hline & Fertilization application \\
\hline & Waste recycling \\
\hline \multirow{11}{*}{$\begin{array}{l}\text { Changes in } \\
\text { traffic }\end{array}$} & Railway \\
\hline & Automobile \\
\hline & Trucking \\
\hline & Shipping \\
\hline & Aircraft \\
\hline & River and canal traffic \\
\hline & Pleasure boating \\
\hline & Trails \\
\hline & Cables and lifts \\
\hline & Communication \\
\hline & Pipeline \\
\hline \multirow{7}{*}{$\begin{array}{c}\text { Waste } \\
\text { emplacement } \\
\text { and treatment }\end{array}$} & Ocean dumping \\
\hline & Landfill \\
\hline & $\begin{array}{l}\text { Emplacement of tailings, spoil and } \\
\text { overburden }\end{array}$ \\
\hline & Underground storage \\
\hline & Junk disposal \\
\hline & Oil well flooding \\
\hline & Deep well emplacement \\
\hline
\end{tabular}


International Journal of Engineering Applied Sciences and Technology, 2021

Vol. 6, Issue 1, ISSN No. 2455-2143, Pages 77-87

Published Online May 2021 in IJEAST (http://www.ijeast.com)

\begin{tabular}{|c|c|}
\hline & Cooling water discharge \\
\hline & $\begin{array}{l}\text { Municipal waste discharge including } \\
\text { spray irrigation }\end{array}$ \\
\hline & Liquid effluent discharge \\
\hline & Stabilization and oxidation ponds \\
\hline & Septic tanks, commercial and domestic \\
\hline & Stack and exhaust emission \\
\hline & Spent lubricants \\
\hline \multirow{5}{*}{$\begin{array}{l}\text { Chemical } \\
\text { treatment }\end{array}$} & Fertilization \\
\hline & Chemical deicing of highways \\
\hline & Chemical stabilization of soils \\
\hline & Weed control \\
\hline & Insect control with pesticides \\
\hline \multirow{3}{*}{ Accidents } & Explosions \\
\hline & Spills and leaks \\
\hline & Operational failure \\
\hline \multirow{2}{*}{ Others } & To be determined \\
\hline & To be determined \\
\hline
\end{tabular}

\section{OTHER NATRIXES VARIANTS}

ML isn't the only one who can spot EIA impacts. The bibliography contains variants and variations of matrix Leopold. They are easily adaptable to a particular activity or undertaking. Table 2's vertical axis depicts the elements that can be impacted, while the horizontal axis lists values ranging from one to five for each element, with one being the lowest and five being the highest.
The magnitude of the effects will always be interpreted by the evaluation team, regardless of the methodology or matrix utilized. To include all components: physical, biological, and social, this team must be interdisciplinary.

One of the shortcomings of these matrices, and the reason for this, is that the judgment is predictable and subjective. As a result, the extent of the effects is a professional evaluator's criterion.

Table 2. Matrix concept from an environmental structure (Canter, 1998)

\begin{tabular}{|c|c|c|c|c|c|}
\hline Identification & \multicolumn{5}{|c|}{ Assessment } \\
\hline \multirow{3}{*}{$\begin{array}{c}\text { Elements/ } \\
\text { environmental units }\end{array}$} & $\begin{array}{c}\text { Scale of } \\
\text { importance }\end{array}$ & $\begin{array}{r}\text { Scale } \\
\text { col }\end{array}$ & $\begin{array}{l}\text { actual } \\
\text { ion }\end{array}$ & $\operatorname{Man}$ & $e^{m e n t}$ \\
\hline & 12345 & \multicolumn{2}{|c|}{12345} & \multicolumn{2}{|c|}{12345} \\
\hline & Low High & Low & High & Low & High \\
\hline \multicolumn{6}{|l|}{ Biologics } \\
\hline \multicolumn{6}{|l|}{ Flora } \\
\hline \multicolumn{6}{|l|}{ Fauna } \\
\hline \multicolumn{6}{|l|}{ Ecological relations } \\
\hline \multicolumn{6}{|l|}{ Physical-chemistry } \\
\hline \multicolumn{6}{|l|}{ Atmosphere } \\
\hline \multicolumn{6}{|l|}{ Water } \\
\hline \multicolumn{6}{|l|}{ Soil } \\
\hline \multicolumn{6}{|l|}{ Cultural } \\
\hline \multicolumn{6}{|l|}{ Housing } \\
\hline \multicolumn{6}{|l|}{ Community } \\
\hline \multicolumn{6}{|l|}{ Economy } \\
\hline \multicolumn{6}{|l|}{ Comunications } \\
\hline \multicolumn{6}{|l|}{$\begin{array}{l}\text { Units/biocultural } \\
\text { relations }\end{array}$} \\
\hline Resource & & & & & \\
\hline
\end{tabular}




\section{International Journal of Engineering Applied Sciences and Technology, 2021 \\ Vol. 6, Issue 1, ISSN No. 2455-2143, Pages 77-87 \\ Published Online May 2021 in IJEAST (http://www.ijeast.com)}

\begin{tabular}{|l|l|}
\hline Leisure & \\
\hline Conservation & \\
\hline
\end{tabular}

The judgment is predictable and subjective, which is one of these matrixes' flaws and the reason behind this. As a result, the magnitude of the effects is a criterion used by professional evaluators. For example, one evaluator may give a flora impact a 4 while another gives it a 5 . (in a scale of $1-5$ )

\section{INTRODUCTION TO THE ENVIRONMENTAL RISK}

Risk is defined as the likelihood of an event occurring and the potential for negative consequences affecting people, animals, property, installations, and the environment. In other words, risk is determined by the likelihood of an accident and the consequences of that accident. (Myles \& Wotherspoon, 1998)

Thus, risk can be expressed by following equation:

$$
\mathrm{R}=\mathrm{PxI}
$$

Where R: risk

$$
\begin{aligned}
& \text { P: probability } \\
& \text { I: impact }
\end{aligned}
$$

Thereafter, to determine the most appropriate methodology is the next step to evaluate the risk.

\section{A. Risk assessment by matrixes.}

A risk classification, similar to EIA, can be constructed based on the risk. Table 3 presents an example of impact and likelihood classification. The probability is separated into low, medium, and high categories in the left column, while the impact is divided into low, medium, and high categories in the right column.

\section{B. Risk assessment by HAZOP}

Hazard and Operability Analysis (HAZOP) is a structured and systematic technique for system examination and risk management. In particular, HAZOP is often used as a technique for identifying potential hazards in a system and identifying operability problems likely to lead to nonconforming products. (PQRI, 2021)

Table 3. Risk matrix according to risk probability and impact (Olaru et al., 2013)

\section{Risk Impact}

\begin{tabular}{|c|c|c|c|}
\hline $\begin{array}{c}\text { Risk ocurrence } \\
\text { probability }\end{array}$ & $\begin{array}{c}\text { Low } \\
\text { (Insignificant, if } \\
\text { only needs be } \\
\text { registered }\end{array}$ & $\begin{array}{c}\text { Average } \\
\text { (reasonable } \\
\text { impact, needs } \\
\text { monitoring) }\end{array}$ & $\begin{array}{c}\text { High (will } \\
\text { have a } \\
\text { significant } \\
\text { impact) }\end{array}$ \\
\hline $\begin{array}{c}\text { Low (less likely to } \\
\text { occur) }\end{array}$ & E & D & C \\
\hline $\begin{array}{c}\text { Average (may occur } \\
\text { a certain point) }\end{array}$ & D & C & B \\
\hline $\begin{array}{c}\text { High (likely to } \\
\text { occur) }\end{array}$ & C & B & A \\
\hline
\end{tabular}

The results of the HAZOP analysis are the team's recommendations, which include identification of hazards and the recommendations for changes in design, procedures, etc. to improve the safety of the system.

Deviations during normal, startup, shutdown, and maintenance operations are discussed by the team and are included in the HAZOP. A block flow diagram of the HAZOP process is given below: (SMS, 2021)

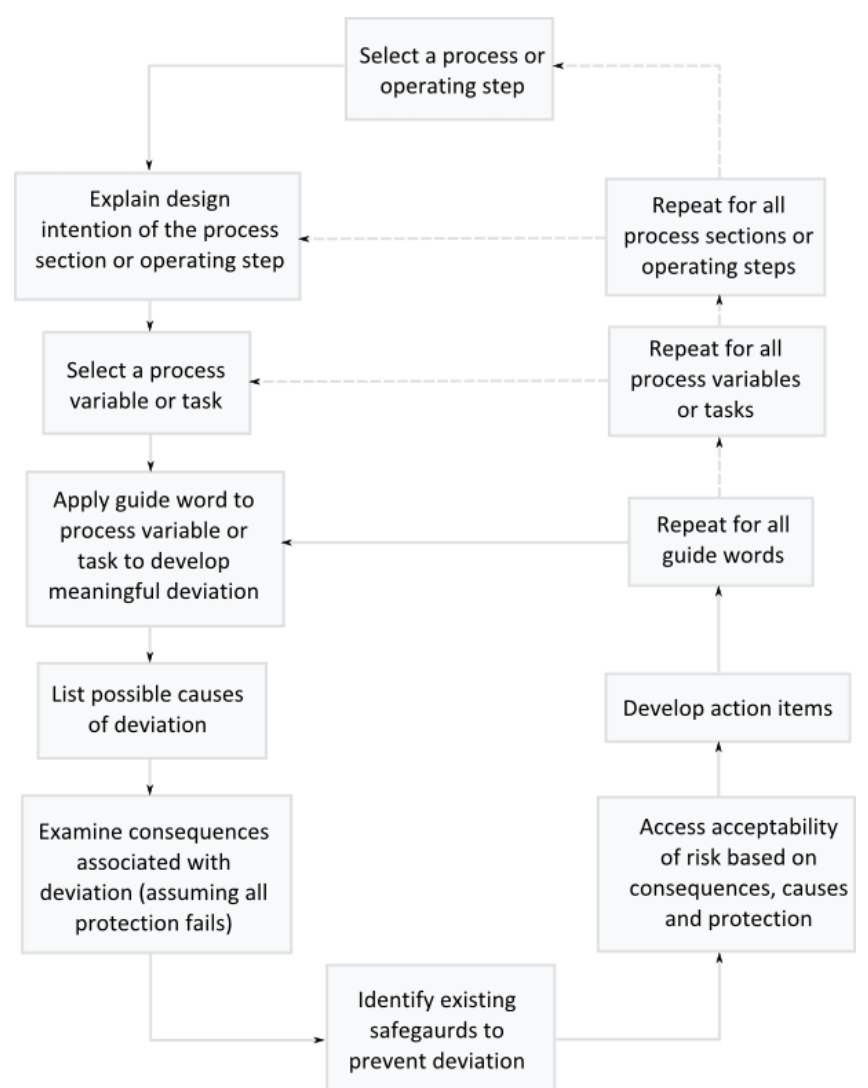

Fig. 2. Block flow diagram of the HAZOP process (SMS, 2021)

A deviation is an abnormal situation of a process that can be identified through the use of guide words and process parameters to generate data: 


\section{International Journal of Engineering Applied Sciences and Technology, 2021 \\ Vol. 6, Issue 1, ISSN No. 2455-2143, Pages 77-87 \\ Published Online May 2021 in IJEAST (http://www.ijeast.com)}

Guide Word + Process parameter $=$ deviation

For example, the following deviations are shown:

Table 4. Set of key words for HAZOP (Mascaro, 2020)

\begin{tabular}{|c|c|c|c|c|}
\hline No & \multirow{6}{*}{+} & Flow & \multirow{6}{*}{$=$} & No flow \\
\hline Plus & & Pressure & & High Pressure \\
\hline Minus & & Temperature & & Low Temperature \\
\hline Other & & Level & & Less level \\
\hline Inverse & & Composition & & Other composition \\
\hline Part of & & Others & & Others \\
\hline
\end{tabular}

As an example, consider a hypothetical risk assessment scenario in which an underground fuel tank is assumed to be installed in the phreatic level y near the surface. To avoid any spills or contamination of ground water reserves, the installation adheres to all civil and mechanical norms. Figure 3 illustrates a basic underground tank.

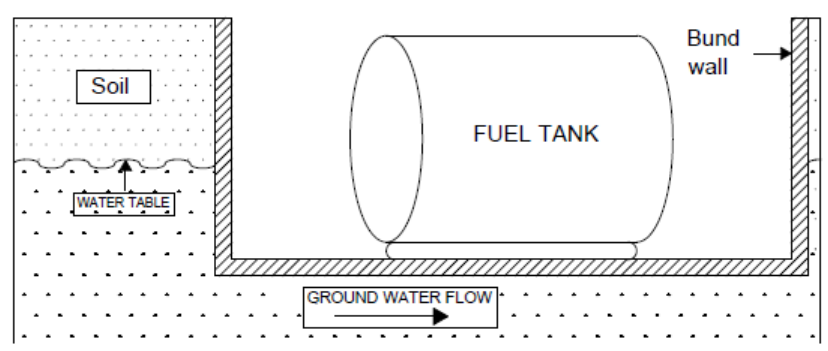

Fig. 3. General configuration of an underground tank fuel

These systems always require a well for monitoring, a double wall to retain the liquid, and hydrocarbon-resistant materials. Given the high phreatic level, there's a possibility that if one of the security measures fails, the hydrocarbons would leak into the groundwater, producing catastrophic consequences. Figure 4 shows the impact on groundwater when wall tanks are the only protection for aquifers due to a failure in the bund wall.

Table 5 shows the HAZOP for the given scenario. In this instance, it is recommended that the tank be installed on the ground rather than underground. It leads to the cancellation of the risk of a high phreatic level, as well as the analysis of other risks.

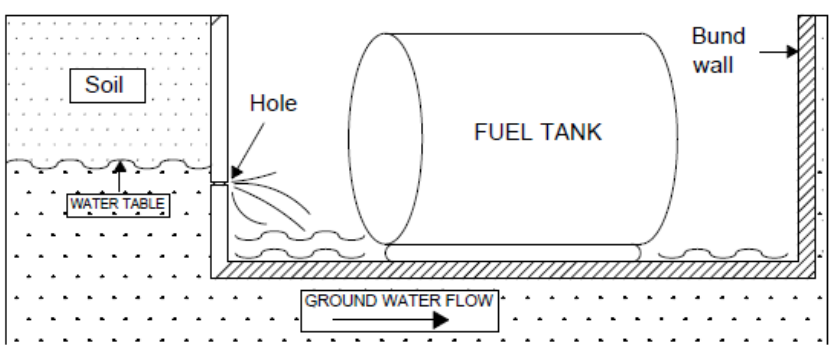

Fig. 4. Failure in bund wall

A software simulation of a pollutant plume caused by a spill is one technique to estimate pollution risk in a more objective way. This is conceivable if the layout of soils and aquifers is known in order to determine the pollutant's direction and reach, which is equivalent to the EIA's influence area.

Table 5. HAZOP analysis for pollution due to high phreatic level

\begin{tabular}{|l|l|l|l|l|}
\hline Deviation & Cause & Consequence & Safeguard & Recommendation \\
\hline $\begin{array}{l}\text { Presence } \\
\text { of fuel in } \\
\text { the bund } \\
\text { wall }\end{array}$ & $\begin{array}{l}\text { Bund wall } \\
\text { failure due to } \\
\text { lack of } \\
\text { maintenance, } \\
\text { poor bund } \\
\text { wall, and a } \\
\text { high phreatic } \\
\text { level }\end{array}$ & & $\begin{array}{l}\text { High risk of } \\
\text { pollution } \\
\text { of fuel by the } \\
\text { walls of the } \\
\text { tank }\end{array}$ & $\begin{array}{l}\text { Analyze the cost- } \\
\text { effectiveness of } \\
\text { installing the tank } \\
\text { above. }\end{array}$ \\
\hline
\end{tabular}

\section{Risk assessment by Fault Tree Analysis (FTA)}

Fault Tree analysis translates the physical system into a logical diagram due to which it is one of the most favored method used these days by the people involved in reliability and safety calculations in industry. It was originated from aerospace industry and then adapted by nuclear power plant industry to qualify and quantify the hazards and risks involve in nuclear power generation. (Baig et al., 2013)

Fault tree analysis can be used to perform for all types of system level risk assessment process. The purpose of FTA is to effectively identify cause(s) of system failure and mitigate the risks before it occurs. (Ramana, n.d.)

FTA uses a variety of symbols to do analysis using event symbols and gates, as seen in tables 6 and 7 .

Table 6. Event symbols in FTA (Ramana, n.d.) 


\section{International Journal of Engineering Applied Sciences and Technology, 2021 \\ Vol. 6, Issue 1, ISSN No. 2455-2143, Pages 77-87 \\ Published Online May 2021 in IJEAST (http://www.ijeast.com)}

\begin{tabular}{|l|l|l|}
\hline S. No & Event Symbol & Description \\
\hline 1 & & $\begin{array}{l}\text { Primary or basic failure event. } \\
\text { It is a random event and } \\
\text { sufficient data is available }\end{array}$ \\
\hline 3 & & $\begin{array}{l}\text { State of system, subsystem or } \\
\text { component event }\end{array}$ \\
\hline 4 & & $\begin{array}{l}\text { Secondary failure or under } \\
\text { develop event, can be explored } \\
\text { further }\end{array}$ \\
\hline 5 & $\begin{array}{l}\text { Conditional event and is } \\
\text { associated with the occurrence } \\
\text { of some other event }\end{array}$ \\
\hline 6 & $\begin{array}{l}\text { House event representing either } \\
\text { occurrence or non-occurrence } \\
\text { of an event }\end{array}$ \\
\hline & $\begin{array}{l}\text { Transfer in and transfer out } \\
\text { symbols used to replicate a } \\
\text { brancj or sub-tree of the FTA }\end{array}$ \\
\hline
\end{tabular}

Table 7. Gate symbols in FTA (Ramana, n.d.)

\begin{tabular}{|l|c|l|}
\hline S. No & Event Symbol & Description \\
\hline 1 & AND Gate & $\begin{array}{l}\text { The output event } \\
\text { occurs when all the } \\
\text { input events occur }\end{array}$ \\
\hline 2 & Priority AND Gate & $\begin{array}{l}\text { The output event } \\
\text { occurs when at least } \\
\text { one of the input events } \\
\text { occur }\end{array}$ \\
\hline 4 & $\begin{array}{l}\text { The output event } \\
\text { occurs when all the } \\
\text { input events occur in } \\
\text { the order from left to } \\
\text { right }\end{array}$ \\
\hline 5 & $\begin{array}{l}\text { Exclusive OR gate } \\
\text { The output event } \\
\text { occurs if either of the } \\
\text { two input events occur } \\
\text { but not both }\end{array}$ \\
\hline Inhibit gate & $\begin{array}{l}\text { The output event } \\
\text { occurs when the input } \\
\text { event occurs and the } \\
\text { attached condition is } \\
\text { satisfied. }\end{array}$ \\
\hline
\end{tabular}

FTA properly applies the fuel leak risk analysis due to a breakdown in the containment system, taking into account the causes listed in table 5 and depicted in figure 5.

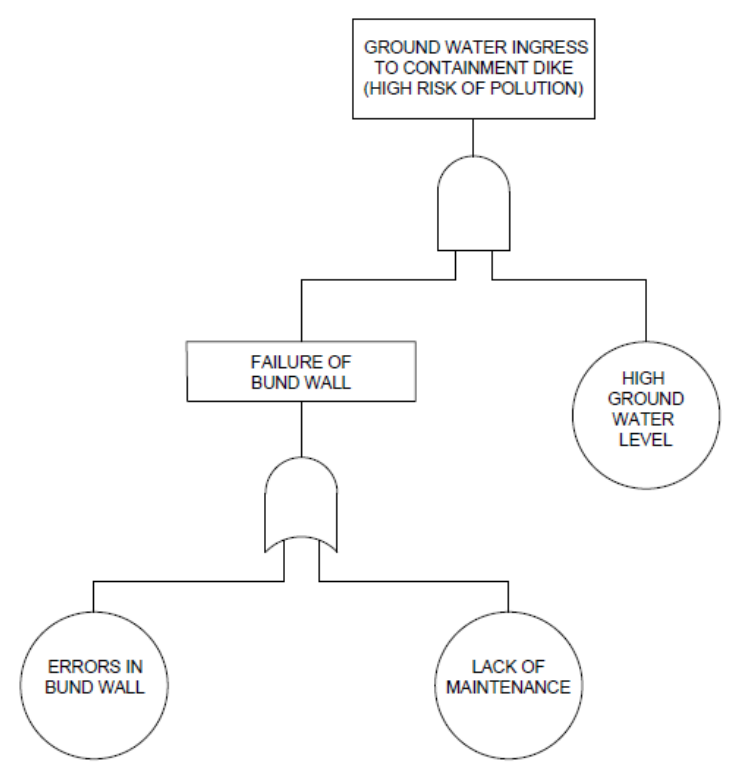

Fig. 5. FTA for a high risk of pollution due to a high phreatic level

Figure 5 shows how to get water into a bund wall by having at least two events occur: bund wall mistakes and/or lack of maintenance, and a high phreatic level in the area.

The same conclusion is reached when evaluating the installation above ground rather than beneath. There is no risk of contamination when a tank is erected on the surface due to the high phreatic level.

It's crucial to note that the analysis presented here is only a small part of a much larger picture, as there are many more variables and factors to consider. Because the tank walls are keeping the fuel flow, there is no contamination even when ground water is in the bund wall. However, there is a considerable chance of contamination at that time since the water has overcome the first barrier, and the second is the last line of defense: the tank walls, necessitating immediate intervention to resolve the problem.

\section{Risk assessment by Monte Carlo method}

The Monte Carlo method is a multi-iterative statistical method, which is based on various repetitive scenarios. It assess the impact on the project from the financial standpoint, but especially in terms of framing established for contractual objectives (Kwak \& Ingall, 2007, as cited in Olaru, M., Sandru, M. \& Carmen, I., 2014). As a result of the Monte Carlo Method, it was possible to assess the impact of different types of risks, including the environmental risks (Olaru, M., Sandru, M. \& Carmen, I., 2014)

Given that there is some uncertainty and variability in the probabilities that are incorporated into the FTA, and additional 


\section{International Journal of Engineering Applied Sciences and Technology, 2021 \\ Vol. 6, Issue 1, ISSN No. 2455-2143, Pages 77-87 \\ Published Online May 2021 in IJEAST (http://www.ijeast.com)}

step of Bayesian statistical approach needs to be added. Bayesian statistical methodologies take into account the variability and distributions of values and uncertainties for variable inputs into a basic FTA. (Fingas, 2017)

With the Monte Carlo Method, specialized software is always used. When data is fed into the software, it runs simulations to assess the risk.

For example, corrosion failure, which can be linked to a lack of maintenance in FTA in figure 5, has occurred many times over time, and thus data is fed into the software to create a frequency distribution, which then leads to an integral analysis for hazardous substance storage risk when combined with the other causes.

The absence of detailed information about prior accidents to determine the likelihood of accidents and their causes is a downside of this strategy.

Some authors have compiled data on past gasoline leak accidents for a specific period of time and geographic location. If data is extrapolated to a different geographic region, uncertainty information might be generated.

\section{COMBINATION OF RISK ANALYSES METHODS}

If a mix of methodologies is used to deal with the reach analysis, a more precise result can be obtained. For example, as previously noted, it is possible to combine an FTA with Monte Carlo simulation, and it is also possible to work with a result from HAZOP with FTA or HAZOP with risk matrix.

\section{CONTAMINATION PREVENTIVE MEASURES}

The steps to limit the danger of contamination were stated in the preceding paragraphs. The following are some instances of measures or elements:

- Bund wall

- Overfilling valves

- Spill containment

- Double tank wall

- Piezometer

- HDPE geomembrane

- Other elements related to static electricity and transport

Following safety regulations is the greatest way to ensure the integrity of the installations. For this type of installation, standards like UL-142 and UL-2085 are widely employed.
These standards are set by the National Fire Protection Association (NFPA) as well as state and local regulations. These are clearly defined in the NFPA 30 Flammable and Combustible Liquids Code. UL-142 is considered one of several standards that are acceptable engineering standards to meet NFPA 30 regulations. (Power products, 2020)

UL-142 is a national standard that covers most types of tanks for flammable and combustible liquids. It also applies to those tanks that are made from steel and located above ground. UL2085 carries many of the same requirements as UL-142. However, it offers specific, stricter requirements for storage tanks. (Power products, 2020)

\section{CONCLUSIONS}

- Hazardous drug handling poses a threat to the environment, necessitating the use of an EIA to assess the physical, biological, and social consequences.

- $\quad$ EIA must be foreseen using a scientifically sound and well accepted technique. The Leopold matrix is a useful matrix that depicts the interactions between impact acts and the environmental parameters that will be impacted.

- Environmental risk assessment assesses the effects of an accident while reducing the possibility of it occurring and negatively impacting human health and the environment.

- Matrixes, HAZOP, FTA, Monte Carlo, and other approaches can be used and blended to assess risk, depending on the scope and information available.

- When EIA is combined with environmental risk assessment, an integrated evaluation can be produced that includes all potentially impacted factors as well as pollution prevention strategies.

- A valuable technique for determining the environmental risk is software that allows the simulation of a contaminated plume before a spill, which requires knowledge of soils and aquifer layout, and thus can identify the pollutant's direction and reach.

- The use of international standards such as UL-142 and UL-2085, which incorporate stringent safety recommendations, is the most effective way to limit the risk of contamination due to hazardous substance storage.

\section{REFERENCE}

[1] Áreas y parques (2020). Áreas Protegidas y Parques Nacionales de Costa Rica. [Protected Areas and National Parks of Costa Rica]. Retrieved from: https://areasyparques.com/areasprotegidas/humedales-decosta-rica/ 


\section{International Journal of Engineering Applied Sciences and Technology, 2021 \\ Vol. 6, Issue 1, ISSN No. 2455-2143, Pages 77-87 \\ Published Online May 2021 in IJEAST (http://www.ijeast.com)}

[2] Baig, A., Ruzli, R., \& Buang, A., (2013). Reliability Analysis Using Fault Tree Analysis: A Review. Universiti Teknologi PETRONAS, Malaysia. DOI: 10.7763/ International Journal of Chemical Engineering and Applications 2013.V4.287

[3] Canter, L (1997). Manual de Evaluación de Impacto Ambiental. 2da Edición [Handbook of Environmental Impact Assessment, $2^{\text {nd }}$ Edition]. McGrawHill/Interamericana de España S.A.U. (pp 75, 96)

[4] Decree 31849 (2004). Reglamento General sobre los Procedimientos de Evaluación de Impacto Ambiental (EIA) [General Regulation on Environmental Impact Assessment Procedures (EIA)]. La Gaceta No. 125. Costa Rica. Retriveed from: http://www.pgrweb.go.cr/scij/Busqueda/Normativa/Norm as/nrm_texto_completo.aspx?param $1=$ NRTC\&nValor $1=1$ \&nValor2=53029\&nValor3=93264\&strTipM=TC.

[5] Decree 32966 (2006). Manual de Instrumentos Técnicos para el Proceso de Evaluación del Impacto Ambiental (Manual de EIA)-Parte IV [Manual of Technical Instruments for the Environmental Impact Assessment Process (EIA Manual)-Part IV]. La Gaceta No. 85. Costa Rica. Retrieved from: http://www.pgrweb.go.cr/scij/Busqueda/Normativa/Norm as/nrm_norma.aspx?param1=NRM\&nValor $1=1 \&$ nValor2 $=57061 \&$ nValor $3=62612 \&$ strTipM=FN

[6] Durán, X. (2020). El bosque de ribera y sus beneficios sobre el ciclo del agua: dos caras de la misma moneda. [The riparian forest and its benefits on the water cycle: two sides of the same coin]. Retrieved from: https://www.iagua.es/blogs/xavi-duran-ramirez/bosqueribera-y-beneficios-ciclo-agua-dos-caras-misma-moneda

[7] EPA (n.d.). Ground Water Contamination. Getting Up to Speed, Wellhead Protection: A Guide for Small Communities. Chapter 3. EPA/625/R-93/002, United States Environmental Impact Agency. Retrieved from: https://www.epa.gov/sites/production/files/201508/documents/mgwc-gwc1.pdf

[8] Fingas, M. (2017). Oil Spill Science and Technology. Second Edition. Spill Science, Edmonton, AB, Canada (pp 95)

[9] Guía Ecológico (2020). La importancia de la vegetación de ribera (bosques de ribera) [The importance of riparian vegetation (riparian forests)]. Retrieved from: https://guiaecologico.wordpress.com/la-importancia-delas-vegetaciones-de-ribera-bosques-de-ribera/

[10] Kwak, Y.H. \& Ingall, L. (2007). Exploring Monte Carlo simulation applications for project management. Risk Management, Vol. 9, No. 1 Feb. 2007, (pp 44-57). doi:10.1057/palgrave.rm.8250017

[11] Mascaro, C. (2020). Webinar: Introducción a la Metodología HAZOP en la Evaluación de Riesgos [Webinar: Introduction to the HAZOP Methodology in
Risk Assessment]. [Video]. YouTube. Retrieved from https://www.youtube.com/watch?v=QuUMt_Z7yOA\&t=3 $992 \mathrm{~s}$

[12] Ministerio de Salud (2004). Emergencias Tecnológicas 2003 [Technology Emergencies 2003]. Risk Office Management. Costa Rica. Retrieved from: https://www.ministeriodesalud.go.cr/gestores_en_salud/ri esgos/emergenciastecnologicas2003.pdf

[13] Ministere de l'Ecologie, de l'energie, du developpement durable et de l'amenagement du territoire (2009). Petrol Station Accidents France, 1958-2007. Version 1 - January 2009, Paris, France. Retrieved from: https://www.aria.developpement-durable.gouv.fr/wpcontent/files_mf/Petrolstations_accidents_jan09.pdf

[14] Myles, J., \& Wotherspoon, P. (1998). Evaluación de Riesgos de Derrames de Hidrocarburos [Oil Spill Risk Assessment]. Guía Arpel. Regional Association of Oil and Natural Gas Companies in Latin America and the Caribbean, Canadian International development Agency Environmental Services Association of Alberta.

[15] Olaru, M., Sandru, M., \& Carmen, I. (2013). Monte Carlo method application for environmental risks impact assessment in investment projects. El Sevier. Procedia Social and Behavioral Sciences 109 (2014) (pp 940 -943).

[16] OSHA (2020). Chemical Hazards and Toxic Substanes. Retrieved from: https://www.osha.gov/SLTC/hazardoustoxicsubstances/

[17] Parkash, S. (2003). Refining Processes Handbook. First edition. Elsevier. United States of America (pp 1)

[18] Petrobras fuel tank explodes in Brazil, killing two (2020). Reuters. Retrieved from: https://www.reuters.com/article/brazil-petrobras-blastidUSL1N11126J20150826

[19] Ponce, V. (2020) The Leopold Matrix for Evaluating Environmental Impact. Retrieved from: http://ponce.sdsu.edu/the_leopold_matrix.html

[20] Powerproducts (2021). What You Need To Know About Storage Tank Standards UL-142 \& UL-2085. Retrieved from: https://www.wpowerproducts.com/news/storagetank-standards/

[21] Ramana, P.V (n.d.). Fault Tree Analysis. Retrieved from: https://sixsigmastudyguide.com/fault-tree-analysis/

[22] PQRI (2021). Risk Management Training Guides. Manufacturng Technology Vomitee - Risk Management Working Group, Product Quality Research Institute, Washington DC, USA. Retrieved from: https://pqri.org/wpcontent/uploads/2015/08/pdf/HAZOP_ Training_Guide.pdf

[23] Sciencing (2020). Fuels Used in Our Daily Life. Retrieved from: https://sciencing.com/fuels-used-daily-life5374489.html 
[24] Silva, D., (n.d). Manual de Sustancias Peligrosas [Handbook of Hazardous Substances]. Chilean Association of Security. AICH. Retrieved from: http://www2.asimet.cl/pdf/msp_ACHS.pdf

[25] Singh, V. \& Lewis, C. (2018). Fire breaks out at Bharat Petroleum plant in Mumbai's Mahul, many injured. The Times of India. Retrieved from: https://timesofindia.indiatimes.com/city/mumbai/firebreaks-out-at-bharat-petroleum-plant-in-mumbaismahul/articleshow $/ 65322476 . \mathrm{cms}$

[26] SMS (2021). HAZOP Basis. Safety Management Services. West Jordan, USA. Retrieved from: https://pqri.org/wpcontent/uploads/2015/08/pdf/HAZOP_Training_Guide.pd f 